\title{
The Role of Marital Relation Strategies on Business Efficacy of Young Male Entrepreneurs with Spousal Involvement and Support as Mediators
}

\author{
Jimmy Ellya Kurniawan, Ersa Lanang Sanjaya \\ School of Psychology, Ciputra University, Surabaya, Indonesia \\ Email: jimmy.ellya@ciputra.ac.id
}

How to cite this paper: Kurniawan, J.E. and Sanjaya, E.L. (2016) The Role of Marital Relation Strategies on Business Efficacy of Young Male Entrepreneurs with Spousal Involvement and Support as Mediators. Open Journal of Social Sciences, 4, 56-66. http://dx.doi.org/10.4236/jss.2016.49007

Received: August 6, 2016

Accepted: September 18, 2016

Published: September 21, 2016

Copyright $\odot 2016$ by authors and Scientific Research Publishing Inc. This work is licensed under the Creative Commons Attribution International License (CC BY 4.0).

http://creativecommons.org/licenses/by/4.0/ (c) (i) Open Access

\begin{abstract}
Many studies about entrepreneurs have already been done from the perspecitve of the individual's characteristics or background, but not many studies have studied it from the marital relationship perspective. The purpose of this study was to investigate the effect of marital relations strategies to business efficacy through mediation of spousal involvement and emotional social support. The subjects were 61 married young male entrepreneurs in Surabaya, Indonesia. Data analysis was tested by using structural equation modeling. Based on the structural equation modeling, only conflict management and advice strategy have a positive impact on the business efficacy of young male entrepreneurs through mediation of their spousal emotional involvement and social support. The other four strategies, namely assurance, openness, positivity and social network have no positive impact toward spousal involvement and spousal emotional social support. Therefore, the four strategies cannot have an effective influence on business efficacy if they are not preceded by a good conflict management strategy.
\end{abstract}

\section{Keywords}

Marital, Relation Strategies, Business Efficacy, Entrepreneur

\section{Introduction}

According to the literature review by Hisrich [1], there are many researches on entrepreneurs based on demographic factors such as gender, education background, occupa- 
tion of their parents, childhood family environment and work history. Results from another review indicate that there has also been plenty of studies on entrepreneurs based on typologies of entrepreneurs, as well as the personality characteristics, motivation and culture of entrepreneurs [1] [2]. Studies of entrepreneurs from family business perspective have also been discovered from family business stories or comparisons between generations in the family [3]. However, there have not been many research done on entrepreneurs based on their marital relationship.

Male entrepreneurs were more likely to have a spouse involved in the business compared to female entrepreneurs [4]. It shows that the spouse, the wife in particular, has an important role in supporting their husband's business venture. Even a wife can become an important stakeholder in building and developing their husband's business [5]. As such, the wife may have a significant role in increasing her husband's business efficacy on developing new ventures. That role could be realized through her involvement and emotional social support toward her husband's business [5]. The wife can also have a direct involvement in supporting her husband's business, such as in helping financial administration, establishing networking, helping the production, marketing and so on [5]. The wife may also be involved indirectly in supporting her husband's business, such as by doing household chores that the husband, who is busy running the business, does not have time to do. Indirect involvement is also an important thing for the husband's business [6]. Emotional social support is also an important role for the wife in improving her husband business efficacy because that support can provide energy for the husband in coping with the stress of running the business [5].

The research results of Danes, Matzek \& Werbel proved the need for spousal involvement and emotional social support during business launch [5]. The results of another study in Indonesia showed that the wife's role is needed not only when launching the husband's business, but also for businesses that has already been running for a long enough time [7]. This assumes that the husband running the businesses still require spousal involvement and emotional social support despite the fact that the business has been running for long enough time.

The problem is that not all husbands can maintain a good marital relationship. According to general statistical data in the province of East Java, Indonesia, the majority of divorces occur in male aged under 45 years or in young adult stage [8]. The young male entrepreneurs, who are in a vulnerable age to divorce, should maintain their marital relationship if they want to have their spouse stay involved and to provide emotional social support for their business. The young male entrepreneurs need to do marital relations strategies in order to enhance their spousal involvement and social emotional support, which at the end will have a good impact for their business efficacy.

There are six strategies on marital relations that will be explored in this study, namely assurance, openness, conflict management, positivity, advice and social network [9] [10]. The purpose of this study was to investigate the effect of marital relations strategies to business efficacy through mediation of spousal involvement and social emotional support. 


\section{Review of Literature}

\subsection{Business Efficacy}

Self-efficacy is the belief in one's capabilities to achieve a certain level or outcome [11]. In the context of entrepreneurship, self-efficacy can be applied to business start-ups and business-growth. Business efficacy could be enhanced if it gets social and instrumental support [12]. Research showed that the patent holders who have high level business efficacy are more successful in business start-up than those who have low business efficacy [13]. Baum \& Locke prove that business efficacy may be associated with new venture growth. [14]. This study will explore business efficacy based on the belief of doing business, maintaining and growing it in the future.

\subsection{Marital Relation Strategies}

Stafford \& Canary developed five maintenance strategies for romantic relationship, ie positivity, openness, assurances, network and shared tasks [10]. Stafford, Dainton \& Haas developed seven strategies that consists of five strategies developed Stafford \& Canary as well as two more additions in conflict management strategy and advice strategy. The study did not use a strategy of shared tasks because it is assumed to be less in line with the culture in Surabaya, which almost always employ a housekeeper meaning couples rarely shared tasks for household chores. As such, there are only six strategies explored in this study, which are assurance, openness, conflict management, positivity, advice and social network [9] [10].

Assurance is a strategy to maintain a relationship with guarantees through commitment or love statements for the spouse. Openness is a strategy to maintain a relationship by opening themselves to the expressed feelings and needs of the spouse. Conflict Management is a strategy to maintain a relationship, by being patient and forgiving to the spouse. Positivity is a strategy to build relations with a pleasant atmosphere in their relationships with their spouse. Advice is a strategy to build relations by giving suggestion or opinion when the spouse is having a problem. Social network is a strategy to build relations using socialization with the same family or relatives as the spouse [9] [10].

\subsection{Spousal Involvement}

Spouse can get involved either directly or indirectly. The wife could be involved directly in support of husband's business, such as helping in financial administration, establish networking, helping the production, marketing and so forth [7]. The wife may also be involved indirectly in supporting their husband's business, such as by doing household chores that the husband, who is busy running the business, don't have time to do. Indirect involvement is also an important thing for the husband's business [6]. In addition to household chores, the wife's involvement in child care can also become indirect support for the husband who are busy doing business [15].

\subsection{Spousal Emotional Social Support}

Act of efficacy requires a certain amount of effort and level of perseverance in order to 
overcome the challenging situation, which requires emotional support in coping with stress. Act of efficacy also needs social support or interaction to strengthen the coping process [16]. Emotional social support can also be associated with information or feedback support from the spouse in strengthening the business-efficacy [5].

\subsection{Research Model}

Marital relations strategies are assumed to improve business efficacy in young male entrepreneurs through spousal involvement and spousal emotional social support as mediators. The complete research model has showed at Figure 1.

Assurance strategy guarantees or assure their love to his wife, which will make her sense of commitment to grow. The wife's commitment will increase her involvement and emotional social support to her husband business [4].

Openness strategy provide clarity of the feelings and needs of the husband toward his wife. Between husband and wife there are different expectations of spousal involvement and emotional social support on business [17], and thus it is necessary to communicate openly to equate their perceptions.

Work family conflict can cause tension in the business. Even spousal commitment toward the business can also increase tension because the husband and wife are competing for a role in managing the business [18]. Conflict management strategy by the husband is required to prevent and resolve conflicts with the wife, so that the wife can get involved and support the husband's business effectively.

Efforts to maintain marital relationship will definitely face many challenges. Spousal gratitude can be one form of protection for marital quality [19], which can increase spousal involvement and emotional social support toward their husband's businesses [4]. Spousal gratitude is a form of positivity strategy that the husband needs to do to his wife. Positive climate interaction will make the wife feel happy to get involved and support her husband's business.

Advice strategy is a social support, especially in informational support, for the wife in

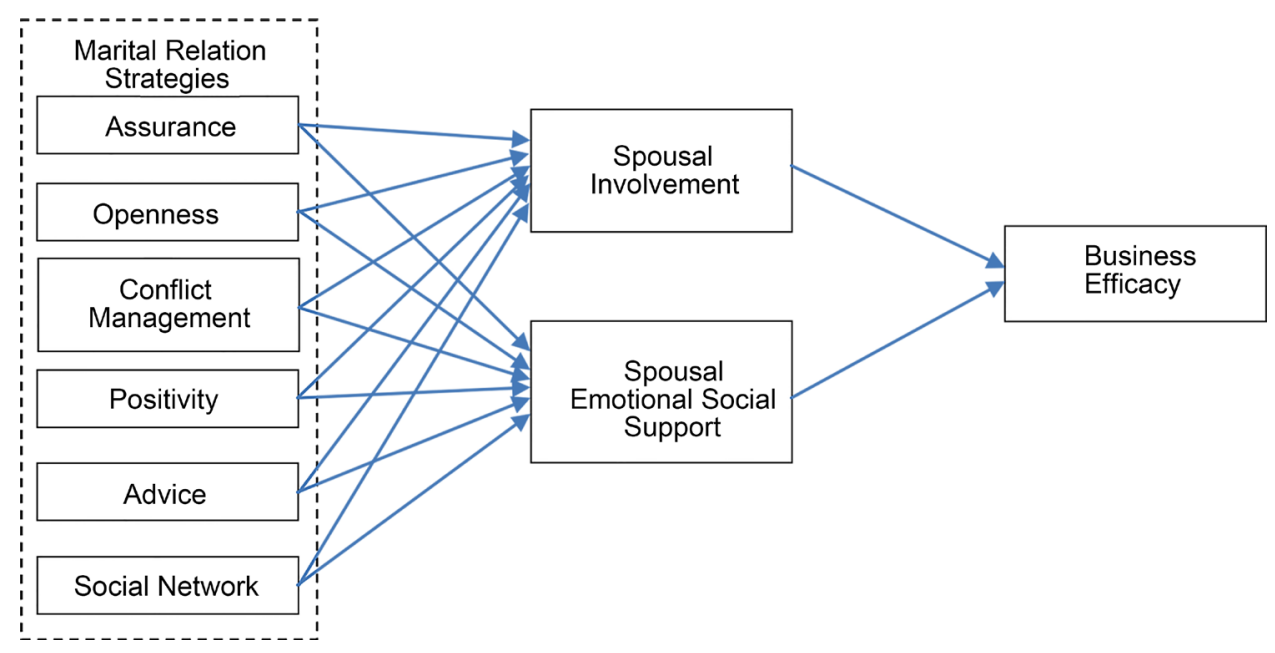

Figure 1. Research model. 
decision making. In general, at domestic life many decisions was made by the husband [20]. But in business life, the role of wife can be more inclusive, including being involved in decision-making, either directly or indirectly [4]. Informational support is needed in the decision-making process [21]. A wife who participates in the decision making will need advice from her husband as an informational support. Therefore, the wife will be more convinced to get involved and support her husband's business.

Social network strategy, or establishing socialization to the same family or relatives, will convince the spouse that they have the same concern and value. Conformity between individual values and organizational values can bring better work performance [22] [23]. Husband and wife who have the same community were assumed to have the same value, so that the wife will not hesitate in getting involved and to support her husband's business.

Based on the descriptions above, the model of this study are as follows at Figure 1.

\section{Method}

\subsection{Participants}

The research subjects in this study were 61 young male entrepreneurs under 45 years old, married, domiciled in Surabaya and surrounding areas. Participants are gathered through the non-random sampling method. Based on the age of the subject, there are 9 people aged under 30 years old, 26 people aged 30 - 39 years old, and 26 people aged 40 - 45 years old. Based on the age of marriage, there are 22 people who have been married for 1 - 5 years, 15 people who had been married for 6 - 10 years and there are 24 people who have been married over 10 years. Based on the length of their running businesses, there are 27 people who have been running the business for 1 - 5 years, 20 people have been running the business for 6 - 10 years, and 14 people have been running the business for more than 10 years. Based on the spousal working status, there are 29 people with a wife who work as a housewife, 20 people have a wife who working outside of the husband's business institution, and 12 people have a wife who working in her husband's business institution.

\subsection{Research Tools}

The method of collecting data in this study uses a questionnaire. All the questionnaires use the Indonesian language. Before the data is collected, the questionnaires were tried out on 30 young male professionals.

Business efficacy scale was measured with a scale developed by the researchers from the concepts of confidence to run a business, maintain, and develop it in the future [11]-[14]. This unidimensional scale consists of three items, prepared using 5-point Likert format with five answer options that are spread from the range of scores $1=$ strongly disagree, to score $5=$ strongly agree. Reliability was measured using Cronbach Alpha and show that $\alpha=0.940$. Example of items on the business efficacy scale was "I belief can maintain business continuity in the future".

Marital Relations Strategies measurement consisting of assurance scale, openness 
scale, conflict management scale, positivity scale, advice scale and social network scale is modified from Stafford, Dainton \& Haas [9] and Stafford \& Canary [10]. All scales using a 5 point Likert format with five answer options that are spread from the range of score $1=$ strongly disagree, to score $5=$ strongly agree. Each scale is unidimensional that consists of three items, except for social network which consists of only two items due to having one invalid item.

Reliability test with Cronbach Alpha showed that the assurance scale has $\alpha=0.812$, openness scale has $\alpha=0.896$, conflict management scale has $\alpha=0.937$, positivity scale has $\alpha=0.849$, advice scales had $\alpha=0.856$ and the social network scale has $\alpha=0.807$. Example of items on the scale of assurance is "I show my love to my wife". Example of items on the openness scale is "I told to my wife about our relationship". Example of items on the conflict management scale is "I can be patient and forgiving my wife." Example of items on the scale of positivity is "I'm trying to make the interaction between us to be fun". Example of items on the advice scale is, "I give advice to my wife when she has a problem". Example of items on the social network scale is, "My wife and I establish relationships together with relatives or family".

Spousal involvement scale was modified from Danes, Matzek \& Werbel [5], consists of three items, and is unidimensional. The scale is prepared using a 5-point Likert format with five answer options that are spread from the range of scores $1=$ strongly disagree, to score $5=$ strongly agree. Scale reliability was measured using Cronbach Alpha and show that $\alpha=0.954$. Examples of items on spousal involvement scale is "My wife is willing to do the things necessary to help my business, either directly or indirectly".

Spousal emotional social support scale was modified from Danes, Matzek \& Werbel [5], consists of three items, and is unidimensional. Scale prepared using 5-point Likert format with five answer options that are spread from the range of scores $1=$ strongly disagree, to score $5=$ strongly agree. Scale reliability was measured using Cronbach Alpha and show that $\alpha=0.870$. Example of items on spousal emotional social support scale was "I feel more relieved after told my business problem to my wife".

\subsection{Analysis}

Analysis data was tested with the structural equation modeling using Smart PLS. Smart PLS is chosen as the method of analysis since the sample size is small and the data does not have a normal distribution.

\section{Results}

The results in Table 1 indicate that spousal involvement has a significantly positive effect toward business efficacy, but only conflict management strategy and advice strategy have a significant positive effect on spousal involvement. Spousal emotional social support also has a significantly positive effect on business efficacy, but only the conflict management strategy has a significantly positive effect on emotional spousal emotional social support. 
Overall, only conflict management strategy and advice strategy are shown to have an indirect positive effect on business efficacy. Squared multiple correlation to business efficacy is 0.350 , which means that the effective contribution of this research is only $35 \%$.

Results of nonparametric correlations matrix with a Spearman's rho in Table 2 shows that all marital relation strategies have a positive correlation toward spousal involvement, spousal emotional social support and business efficacy. Spousal involvement and spousal emotional social support are also positively correlated with business efficacy.

Table 1. Table path coefficient.

\begin{tabular}{lcc}
\hline \multicolumn{1}{c}{ Path } & T-Statistics & P-Value \\
\hline Assurance $\rightarrow$ Spousal Involvement & 0.838 & 0.201 \\
Assurance $\rightarrow$ Spousal Emotional Social Support & 0.575 & 0.283 \\
Openness $\rightarrow$ Spousal Involvement & 0.853 & 0.197 \\
Openness $\rightarrow$ Spousal Emotional Social Support & 0.875 & 0.191 \\
Conflict Management $\rightarrow$ Spousal Involvement & 1.763 & $0.039^{*}$ \\
Conflict Management $\rightarrow$ Spousal Emotional Social Support & 1.843 & $0.033^{*}$ \\
Positivity $\rightarrow$ Spousal Involvement & 0.400 & 0.345 \\
Positivity $\rightarrow$ Spousal Emotional Social Support & 1.136 & 0.128 \\
Advice $\rightarrow$ Spousal Involvement & 2.017 & $0.022^{*}$ \\
Advice $\rightarrow$ Spousal Emotional Social Support & 0.264 & 0.396 \\
Social Network $\rightarrow$ Spousal Involvement & 0.157 & 0.438 \\
Social Network $\rightarrow$ Spousal Emotional Social Support & 0.097 & 0.461 \\
Spousal Involvement $\rightarrow$ Business Efficacy & 1.680 & $0.047^{*}$ \\
Spousal Emotional Social Supoort $\rightarrow$ Business Efficacy & 2.829 & $0.002^{*}$ \\
\hline
\end{tabular}

*Significant for one tail analysis $(\mathrm{p}<0.05)$.

Table 2. Mean, standard deviation and correlation matrix.

\begin{tabular}{|c|c|c|c|c|c|}
\hline $\begin{array}{l}\text { Marital Relation } \\
\text { Strategies }\end{array}$ & Mean & $\begin{array}{l}\text { Standard } \\
\text { Deviation }\end{array}$ & $\begin{array}{c}\text { Spousal } \\
\text { Involvement }\end{array}$ & $\begin{array}{l}\text { Spousal Emotional } \\
\text { Social Support }\end{array}$ & $\begin{array}{l}\text { Business } \\
\text { Efficacy }\end{array}$ \\
\hline Assurance & 13.984 & 1.499 & $\begin{array}{c}0.386 \\
p=0.001^{*}\end{array}$ & $\begin{array}{c}0.539 \\
\mathrm{p}=0.000^{*}\end{array}$ & $\begin{array}{c}0.384 \\
\mathrm{p}=0.001^{\star}\end{array}$ \\
\hline Openness & 13.705 & 1.892 & $\begin{array}{c}0.446 \\
\mathrm{p}=0.000^{*}\end{array}$ & $\begin{array}{c}0.515 \\
p=0.000^{*}\end{array}$ & $\begin{array}{c}0.382 \\
\mathrm{p}=0.001^{\star}\end{array}$ \\
\hline Conflict Management & 13.721 & 1.614 & $\begin{array}{c}0.452 \\
\mathrm{p}=0.000^{*}\end{array}$ & $\begin{array}{c}0.642 \\
p=0.000^{*}\end{array}$ & $\begin{array}{c}0.540 \\
\mathrm{p}=0.000^{*}\end{array}$ \\
\hline Positivity & 13.918 & 1.358 & $\begin{array}{c}0.361 \\
\mathrm{p}=0.002^{*}\end{array}$ & $\begin{array}{c}0.697 \\
\mathrm{p}=0.000^{*}\end{array}$ & $\begin{array}{c}0.488 \\
\mathrm{p}=0.000^{*}\end{array}$ \\
\hline Advice & 13.361 & 1.506 & $\begin{array}{c}0.502 \\
p=0.000^{*}\end{array}$ & $\begin{array}{c}0.364 \\
p=0.002^{*}\end{array}$ & $\begin{array}{c}0.324 \\
p=0.005^{\star}\end{array}$ \\
\hline Social Network & 8.574 & 1.596 & $\begin{array}{c}0.355 \\
\mathrm{p}=0.002^{*}\end{array}$ & $\begin{array}{c}0.424 \\
\mathrm{p}=0.000^{*}\end{array}$ & $\begin{array}{c}0.430 \\
\mathrm{p}=0.000^{*}\end{array}$ \\
\hline Spousal Involvement & 12.934 & 2.128 & & $\begin{array}{c}0.518 \\
p=0.000^{\star}\end{array}$ & $\begin{array}{c}0.337 \\
\mathrm{p}=0.004^{\star}\end{array}$ \\
\hline $\begin{array}{l}\text { Spousal Emotional } \\
\text { Social Support }\end{array}$ & 13.443 & 2.187 & & & $\begin{array}{c}0.476 \\
\mathrm{p}=0.000^{*}\end{array}$ \\
\hline Business Efficacy & 13.984 & 1.765 & & & \\
\hline
\end{tabular}

${ }^{*}$ Significant $(\mathrm{p}<0.05)$. 
Based on the description in Table 1 and Table 2, it can be concluded that only conflict management strategy and advice strategy have indirect positive effects toward business efficacy through mediation of spousal involvement and spousal emotional social support. Despite that all the marital relation strategies having positive correlation to the spousal involvement, spousal social emotional support and business efficacy, only conflict management strategy and advice strategy contributes effectively for business efficacy.

\section{Discussion}

Decision making in domestic life is mostly done by the husband [20]. In the traditional family, it is the husband who controls all domestic policies, from financial policy to parenting [24]. This research was conducted in Surabaya, which is a city on Java Island, Indonesia. In Java, the husband has a greater role in decision making, while the wife is in charge financial administration and parenting [25].

The role of the husband as the head and decision maker in households and businesses leaves the wife unable to take decisions freely. Even though at times the wife is involved in the decision-making of business related matters [21], she still needs the advice of her husband when she's facing problems. Even in the domestic affairs, the wife still need suggestions from her husband so that she doesn't make a mistake in deciding financial related matters or in child care. Often, the wife feels stressed by the multiple roles she had to do, which is between family care, to assist her husband's business or to finish her own professional jobs. The wife with multiple roles should get informational support or positive advice so that the wife is able to cope with stress [26]. Support from the husband, which includes giving information or advice, can increase the involvement of his wife in the family business [27]. The suggestions of the husband as a decision maker in the family would make his wife more comfortable when she's being involved in helping husband's business, either directly or indirectly.

Results of research from Werbel \& Denes indicated that work family conflict may hamper new business ventures. The results also revealed that businessmen tend to be more easily affected by spousal strain than businesswomen. Greater spousal commitment will also increase that strain, which means that conflict management is needed in order to keep the sustainability of the business [28]. Spousal commitment can be reflected in spousal involvement and spousal emotional social support can have bad impact if the work family conflict stays unresolved. Problems in marriage relationships at home can make the spouse not involved and support effectively toward the husband's business. Even if the wife attempts to get involved or support, it could be misunderstood by the husband which means it will not increase his business efficacy. The husband who manage the conflict should reconcile the marriage relationship so that the spousal involvement and emotional social support would be more effective in increasing the efficacy of his business.

The other strategies, i.e. assurance, openness, positivity and social network does not affect either toward the spousal involvement or the spousal emotional social support. 
Stafford \& Canary proved that the four strategies are positively correlated to commitment [10]. Assurance strategy guarantees or assure their love to his wife, which will make her sense of commitment to grow [4]. Openness strategy will provide clarity of the feelings and needs of the husband toward the wife in order to cultivate her commitment [17]. Positivity strategy can become one form of protection for marital quality that is also able to make her commitment grow [19]. Social network strategy, or establishing socialization to the same family or relatives would assure the wife that they have the same concerns and values, can also grow her commitment [20].

On the other hand, Werbel \& Denes explains that as long as the work family conflict has not been completely managed, then the spousal commitment would only increase the strain and hamper the business sustainability. [18]. Spousal commitment in this research is reflected in spousal involvement and spousal emotional social support. Therefore, the four strategies, namely assurance, openness, positivity and social network, cannot effectively influence the spousal involvement and social emotional spousal support if it is not preceded by a good conflict management strategy.

Suggestions for further research need to factor analysis on whether the strategy of assurance, openness, positivity and social network can stand alone as independent dimension or as part of conflict management strategy. Further studies are also needed to discover the concrete strategy of conflict management and the specific kind of advice to the spouse in increasing the business efficacy on the young male entrepreneurs.

\section{Conclusions}

This study proves that only conflict management strategy and advice strategy have an indirect positive effect toward business efficacy through the mediation spousal involvement and spousal emotional social support. The other four strategies, namely assurance, openness, positivity and social network cannot effectively influence the spousal involvement and emotional social support if it is not preceded by a good conflict management strategy.

Future studies are recommended to test whether other fourth strategies can be independent startegy or be part of other strategies that have a positive effect in this study. Concrete strategies of conflict management and advice also need to be explored in future studies. Spousal involvement and support also need to discovered based on demographic factors such as age of businessman, age of his spouse, age of marriage, length of running business, and spousal working status in further research.

\section{Acknowledgements}

We acknowledge the support and generosity of Kemenristek Dikti Republic of Indonesia that supported with Penelitian Hibah Bersaing (PHB)/Penelitian Produk Terapan (PPT) 2016 for this research.

\section{References}

[1] Hisrich, R.D. (1990) Entrepreneurship/Intrapreneurship. American Psychologist, 45, 209- 
222. http://dx.doi.org/10.1037/0003-066X.45.2.209

[2] Hisrich, R., Langan-Fox, J. and Grant, S. (2007) Entrepreneurship Research and Practice: A Call to Action for Psychology. American Psychologist, 62, 575-589.

http://dx.doi.org/10.1037/0003-066X.62.6.575

[3] Smith, R. (2014) Authoring Second-Generation Entrepreneur and Family Business Stories. Journal of Family Business Management, 4, 149-170. http://dx.doi.org/10.1108/JFBM-11-2011-0050

[4] Matzek, A.E., Gudmunson, C.G. and Danes, S.M. (2010) Spousal Capital as a Resource for Couples Starting a Business. Family Relations, 59, 60-73.

http://dx.doi.org/10.1111/j.1741-3729.2009.00586.x

[5] Danes, S.M., Matzek, A.E. and Werbel, J.D. (2010) Spousal Context during the Venture Creation Process. Entrepreneurship and Family Business: Advances in Entrepreneurship, Firm Emergence and Growth, 12, 113-161. http://dx.doi.org/10.1108/S1074-7540(2010)0000012007

[6] Rosenblatt, P.C., de Mik, L., Anderson, R.M. and Johnson, P.A. (1985) The Family in Business. Jossey-Bass, San Francisco.

[7] Mahastanti, L.A. and Nugrahanti, Y.W. (2010) Peranan Wanita Pendamping Suami Menjalankan Bisnis Keluarga dalam Pengembangan Bisnis: Studi Industri Kecil Kerupuk di Tuntang Kabupaten Semarang. Jurnal Siasat Bisnis, 14, 43-58.

http://journal.uii.ac.id/index.php/JSB/article/viewFile/2028/1782

[8] Badan Pusat Statistik (2010) Sesnus Penduduk Provinsi Jawa Timur Tahun 2010. http://sp2010.bps.go.id/index.php/site/tabel?tid $=267 \&$ wid $=3500000000$

[9] Stafford, L., Dainton, M. and Haas, S. (2000) Measuring Routine and Strategic Relational Maintanance: Scale Revision, Sex versus Gender Roles, and the Predicton of Relational Characteristic. Communication Monograph, 67, 306-323. http://dx.doi.org/10.1080/03637750009376512

[10] Stafford, L. and Canary, D.J. (1991) Maintanance Strategic and Romantic Relationship Type, Gender and Relational Characteristics. Journal of Social and Personal Relationship, 8, 217-242. http://dx.doi.org/10.1177/0265407591082004

[11] Bandura, A. (1986) The Social Foundations of Thought and Actions. Prentice-Hall.

[12] Dronvsek, M., Wincent, J. and Cardon, M.S. (2010) Entrepreneurial Self-Efficacy and Business Start-Up: Developing a Multi-Dimensional Definition. International Journal of Entrepreneurial Behaviour \& Research, 16, 329-348. http://dx.doi.org/10.1108/13552551011054516

[13] Markman, G.D., Baron, R.A. and Balkin, D.B. (2005) Are Perseverance and Self-Efficacy Costless? Assessing Entrepreneurs' Regretful Thinking. Journal of Organizational Behavior, 26, 1-19. http://dx.doi.org/10.1002/job.305

[14] Baum, J.R. and Locke, E.A. (2004) The Relationship of Entrepreneurial Traits, Skill, and Motivation to Subsequent Venture Growth. Journal of Applied Psychology, 89, 587-598. http://dx.doi.org/10.1037/0021-9010.89.4.587

[15] Marshack, K.J. (1993) Counterpreneurial Couples: A Literature Review on Boundaries and Transitions among Copreneurs. Family Business Review, 6, 355-369.

http://dx.doi.org/10.1111/j.1741-6248.1993.00355.x

[16] Han, W.T., Collie, K., Koopman, C., Spiegel, D., et al. (2005) Breast Cancer and Problem with Medical Interactions: Relationship with Traumatic Stress, Emotional Self-Efficacy, and Social Support. Psycho-Oncology, 14, 318-330. http://dx.doi.org/10.1002/pon.852

[17] Craft, S.M., Seal, K.L., Jang, J. and Danes, S. (2015) Spousal Expectations and Perceived So- 
cial Support during the Creation of a New Business Venture. Journal of Couple \& Relationship Therapy, 14, 169-195. http://dx.doi.org/10.1080/15332691.2014.921263

[18] Werbel, J.D. and Danes, S.M. (2010) Work Family Conflict in New Business Ventures: The Moderating Effects of Spousal Commitment to the New Business Venture. Journal of Small Business Management, 48, 421-440. http://dx.doi.org/10.1111/j.1540-627X.2010.00301.x

[19] Barton, A.W., Futris, T.G. and Nielsen, R.B. (2015) Linking Financial Distress to Marital Quality: The Intermediary Roles of Demand/Withdraw and Spousal Gratitude Expressions. Personal Relationships, 22, 536-549. http://dx.doi.org/10.1111/pere.12094

[20] Willigen, M.V. and Drentea, P. (2001) Benefits of Equitable Relationships: The Impact of Sense of Fairness, Household Division of Labor, and Decision Making Power on Perceived Social Support. Sex Roles, 44, 571-597. http://dx.doi.org/10.1023/A:1012243125641

[21] Sadovykh, V., Sundaram, D. and Piramuthu, S. (2015) Do Online Social Networks Support Decision-Making? Decision Support Systems, 70, 15-30. http://dx.doi.org/10.1016/j.dss.2014.11.011

[22] Anderson, N., Ones, D., Sinangil, H. and Viswesvaran, C. (Eds.) (2001) Handbook of Industrial, Work, and Organizational Psychology. Vol. 2, Sage Publications, Thousand Oaks.

[23] Borman, W.C., Ilgen, D.R. and Klimoski, R.J. (2003) Handbook of Psychology. Vol. 12: Industrial \& Organizational Psychology. John Wiley \& Sons Inc., Hoboken.

[24] Surbakti, E.B. (2008) Sudah Siapkah Menikah. Elex Media Komputindo, Jakarta.

[25] Putri, D.P.K. and Lestari, S. (2015) Pembagian Peran Dalam Rumah Tangga Pada Pasangan Suami Istri Jawa. Jurnal Penelitian Humaniora, 16, 72-85.

[26] Van Steenbergen, E.F., Ellemers, N., Haslam, S.A. and Urlings, F. (2008) There Is Nothing either Good or Bad but Thinking Makes It So: Informational Support and Cognitive Appraisal of the Work-Family Interface. Journal of Occupational and Organizational Psychology, 81, 349-367. http://dx.doi.org/10.1348/096317908X312669

[27] Nisa, Z. and Hilman, F. (2014) Pengaruh Resiliensi dan Dukungan Sosial Keluarga terhadap Keterlinatan Kerja Istri dalam Bisnis Keluarga. Electronic Theses \& Dissertations (ETD), Gadjah Mada University, Gadjah Mada.

http://etd.repository.ugm.ac.id/index.php?act=view\&buku_id=78055\&mod=penelitian_det $\underline{\text { ail\&sub }=\text { PenelitianDetail\&typ }=\text { html }}$

[28] Werbel, J.D. and Danes, S.M. (2010) Work Family Conflict in New Business Ventures: The Moderating Effects of Spousal Commitment to the New Business Venture. Journal of Small Business Management, 48, 421-440. http://dx.doi.org/10.1111/j.1540-627X.2010.00301.x 
Submit or recommend next manuscript to SCIRP and we will provide best service for you:

Accepting pre-submission inquiries through Email, Facebook, LinkedIn, Twitter, etc. A wide selection of journals (inclusive of 9 subjects, more than 200 journals)

Providing 24-hour high-quality service

User-friendly online submission system

Fair and swift peer-review system

Efficient typesetting and proofreading procedure

Display of the result of downloads and visits, as well as the number of cited articles

Maximum dissemination of your research work

Submit your manuscript at: http://papersubmission.scirp.org/

Or contact jss@scirp.org 